\title{
Jawi Writing in Malay Archipelago Manuscript: A General Overview
}

\author{
Makmur Haji Harun 1,*, Mohd Kasturi Nor Abd Aziz², Edzham Armin Abd Rahim², Shuhairimi A. ${ }^{2}$, and Yasmin \\ $\mathrm{Ahmad}^{2}$ \\ ${ }^{1}$ Faculty of Languages and Communication, Universiti Pendidikan Sultan Idris(UPSI), 35900 Tanjong Malim, Perak, Malaysia \\ ${ }^{2}$ School of Human Development and Techno-communication, Universiti Malaysia Perlis, Perlis, Malaysia
}

\begin{abstract}
Jawi writing is the main form of writing in various manuscripts recovered around the Archipelago, especially during the early arrival of Islam. These manuscripts are found to record history, art, culture, language, social, as well as ancient knowledge. . The usage of Jawi writings had covered a number of calligraphy which are high in value with deep philosophical meaning, are full with creative notion as well as countless of patterns that went along with the call to Islam around the Archipelago in a relatively short period of time. The development of Jawi writing had been immortalized in various genres such as books, manuscripts and letters written by individual writers and in groups as a local way of living. This writing was also introduced through a long process using certain methods of writing and reading, and kept as individual as well as institutional collections all around the Archipelago. This article is focused in various manuscripts that not only were exclusively used as learning and teaching aids, but were also garnished as beautiful symbols and philosophical Islamic art that deserves a high degree of honour. This article's objective is to deeply analyze the usage of this writing from manuscripts found around the Archipelago as a proof on the importance of this form of writing. The methodology of this article is library study, through a number of theories and methods. The implication of this article is hoped to form a certain standard as well as its own identity for the local society through their acceptance of this writing form, especially during the early arrival of Islam in the Archipelago thus deemed as a national treasure.
\end{abstract}

\section{Introduction}

Through the reading of Malay manuscripts it can be one of the discloser to treasure Jawi writing in the form of historical, cultural, social, science, and knowledge of the past. Jawi cover various types of calligraphy with elements of high value art, has a philosophical, creative laden with meaning, have diverse patterns of spread together with Islam in a short time almost all regions of the country. Raising various manuscripts written in Jawi, it is not just as a teaching and learning, but also can be a beautiful decoration in the form of works of art and heritage of Jawi calligraphy patterns, styles, colors, symbols and philosophy of credible Islamic art. Various collections of Jawi manuksrip can be found as calligraphy using nasakh, but there is also a wide variety of other khat as a step to strengthen the position of writing and mastery of many beautiful and wonderful as a civilized and dignified nation's heritage. This study is conucted to discuss the issue as a joint search for identity in addition to getting to know and understand the use of
Jawi writing a paper base to produce manuscripts written in Jawi in Malay, in addition to being one of the discourse of science that can uncover the richness of spoken and written of the Muslim community in Nusantara.

\section{Brief view on Malay manuscript}

Jawi was instrumental in establishing communication through writing, even a spoken language among the Malay community in the archipelago. Language and Jawi revealing the identity of the Malay, Jawi to relay communication and language of the Malays who come grow together with the science of philology and their manuscripts. Therefore, the Jawi script in various manuscripts in the Malay used mostly as a tool to understand the culture of his people, especially the language used in the review of the manuscript heritage as a nation. The following display is the debate on the study of ancient manuscripts that flourished in the

* Corresponding author: makmur@,fbk.upsi.edu.my 
archipelago that is the legacy of their ancestors from time to time. Multiple exposure will be displayed as a study in the question of whether art, culture, language, sciences, and other knowledge through various mansukrip in Jawi.

In the 4th century $\mathrm{AD}$ where several cities in West Asia have college as a center of research knowledge that comes from the Renaissance, Greek, Byzantine and Western, and Alexandria. All of these places become centers of research manuscripts and manuscript whose influence has spread from time to time. Scientific studies also cover various fields of science, philosophy, art, culture, science and technology come to grow and spread until it reaches areas of Malaya. Since the archipelago nation, especially the Malays literacy, especially after the advent of Islam to the Malay world, the greater part of the society is to cultivate write in their manuscript copies and so it can form a document that gives information about their life in the past. Among the Asian nations that are considered pretty much had the documents they are relics of the past India. It was revealed from various research and studies to document their research mainly in the form of writing such as stone inscriptions, manuscripts and inscriptions of ancient relics of their ancestors when compared with the Malays. While the early development of writing in Indonesia is not yet known, because it is considered as the expertise of its own and only certain people only knew, not even many of the civil society who control except from certain groups or writers castle alone.

There is language in the script used in conveying information, also used in the writing of the manuscript as a tool to know the culture of a nation included in the Malay world. The existence of the manuscripts in the Malay heavily influenced by the languages that have the time, among others derived from Sanskrit, Tamil, Arabic, Persian and regional languages cognate's manuscripts. But the languages most influential manuscripts in the archipelago are Sanskrit and Arabic. Therefore, to understand and study the manuscripts are available in the archipelago in the study of philology, then both of these languages are necessary to learn and even be controlled, such as studies manuscripts Javanese texts and copies of classic Malay.

In ancient manuscripts they are very much influenced by Sanskrit, such as the effect on the absorption of vocabulary, phrases, syntax and excerpts sometimes without translation. As an example of these influences can be seen in Uttarakanda, Kakawin Ramayana and Sanghyang Kamahikan. Although the ancient Malay manuscripts also involve Sanskrit but only the form of a loan word that remains sahaja required. For old Malay manuscripts, knowledge of Arabic is also needed; especially for study of manuscripts rather than the influence of Islam in particular that contains the teachings of Islam and Sufism or Suluk. Because in these manuscripts contained many serpan such as words, phrases, expressions, and excerpts-excerpts in Arabic.

In addition to foreign languages, the regional languages in the archipelago are also indispensable in the cultivation of which produces manuscripts archipelago, that language is a communication substitutions tribal areas of the archipelago which is closely related to the language manuscripts. Knowledge of languages is important because controlled cultivation of manuscripts sometimes disukarkan reading words that it was not coming out of a foreign language, but precisely than the local language and the local language, including the manuscripts beraksara Jawi, Java script pegon and other characters.

\section{Expansion Study on Malay Manuscript}

The development of the expansion of the manuscript on the next stage of Malaya, estimated in the 12th century $\mathrm{AD}$, the community has not yet used the Jawi script immediately but they use scripts and manuscripts Jawi existing for the purpose of writing, so it appears inscribed stone, which is the initial document evidence of Jawi writing in the Malay already begun. His appearance is directly related to the arrival of Islam to the archipelago. This character is based on the Arabic script used for writing Malay speech. Thus, there is inevitably some point additions or modifications to adjust the sound does not exist in Arabic (eg, speech / o /, / p /, or $/ \mathrm{n} /$ ).

After the earliest evidence of Jawi script is in Malaysia with an inscribed Terengganu Stone is dated $702 \mathrm{H}$ or 14th century $\mathrm{AD}$ (the date is quite a problem because the number of years of writing, not with numbers). Here only can read seven hundred and two $(702 \mathrm{H})$. But this can be followed by two other words namely 20 to 29 or - eight -> two eight -> "eight". This word can also be followed by the word "nine". With this, it becomes more likely date being 702, 720-729, or 780$789 \mathrm{H}$. But since this Inscription Stone also mentioned that this year is the "Year of the Crab", then there are only two possibilities left namely in $1326 \mathrm{M}$ or $1386 \mathrm{M}$. But according to Muhammad Naquib al-Attas, that the inscribed stone that was written in the year $702 \mathrm{H}$ equal to the year $1303 \mathrm{AD}$ its content emphasizes the rulings of fiqh, also using the Jawi script which is a translation of religious books entitled 'Aqa' id al-Nasafi.

Jawi manuscript writing and keeping pace with the spread of Islam and managed to build a society with a culture in line with Islam (Ismail Hussein, 1984). Activities continued with writing letters of various materials there is a peak in the 17 th century AD when it appears influential figures such as Hamzah Fansuri and Nuruddin ar-Raniri (r.h) and so on. Persian scholars and scholars from many contributions in the fields of politics, trade, social, culture and religion, but also wellknown as a center of Pasai Malay language and literature (T. Iskandar, 1995). Developments in the field of literature very rapidly as writing literary works in Malay and Jawi writing is widely used not only in society even among people of the castle (Ismail Hussin, 1984).

\section{Jawi Written Manuscript Studies in the Malay World}

In this century, hundreds and even thousands of manuscripts written in various areas in the Malay world, 
especially in the palaces and administrative centers. While writing the Malay manuscripts which often featured in masyarakatny is covering all fields. Malay Jawi manuscripts collection estimated at 265 title handwritten manuscripts written in Jawi Malay and other languages. This has opened up a special research in the field of Malay writing. Among the titles that is often referred to Sulalatus Salatin, Hikayat Amir Hamzah, Hikayat Indera Putera, Panji and others (Digital Library DBP). The following description of some examples of Malay manuscripts which often become the reference in the archipelago. According to the detailed description as follows;

\subsection{Manuscript 'Hikayat Raja-Raja Pasai’}

The manuscript is believed to be the oldest book in Malay literature. It is a story about the discovery of the 16th century. The manuscript is believed to be one of the original copies of previous issues. Hikayat Raja-Raja Pasai this is a literary masterpiece that is the oldest history of Islam Nusantara. In the manuscript was told of important events that occurred between the years 1250$1350 \mathrm{AD}$. This period is the reign of King Merah Silu who later converted to Islam and changed his name as Malik al-Salih.

The manuscript of this saga is the only step the history of the kingdom Pasai ever successful when used in the archipelago. According to estimates by Russel Jones saga was written in the 14th century. This saga also includes the establishment of the Sultanate of Samudera Pasai until the conquest by the kingdom of Majapahit. In addition, the contents of the Hikayat RajaRaja Pasai is told about the elements of legalization of family members of the ruling, stating the origin of the sacred family. In addition, the manuscript also has a didactic function, such as a tyrannical king will be punished, and the country will be destroyed. Likewise with Sultan Malik al-Mansur who seized his concubine. At the same where Sultan Ahmad who is jealous of his sons, causing their second murder.

Manuscript "Hikayat Raja-Raja Pasai" has striking similarities in the composition of the subject and verse with "Sejarah Melayu." "Hikayat Raja-Raja Pasai" is one source of the story of the coming of Islam to the West it also is a work in Malay which tells the story of the first Islamic kingdom in the archipelago, SamuderaPasai which is now located in Nanggroe Aceh Darussalam.

\subsection{Manuscript 'Hikayat Amir Hamzah'}

Hikayat Amir Hamzah was initially written by a Persian writer with Qissa'i title Emir Hamzah and then translated into Arabic with the title Sirat Hamzah. This manuscript was brought by missionaries from India to Melaka in Melaka Malay Sultanate era. This manuscript was copied by hand by the author of the palace of King Melaka when it takes over 15 years to complete the whole text. Besides Malay language, this manuscript is written in Java, Bali, Aceh, Turkish and Hindi.
The main character in this story is Hadrat Hamzah; the Islamic warriors were killed in the battle of Uhud. In accordance with the saga of the story has been exaggerated. Amir Hamzah described so great for example as follows:
Due to the strength of Amir Hamzah shouts can be heard up to 18 winds away. The tiger heard the shout of surprise ran. The camel and horse flopped. The arrows in the hands of his enemies fall to the ground.

\subsection{Manuscript 'Hikayat Hang Tuah'}

Hikayat Hang Tuah manuscript is written in Jawi. This manuscript is a heroic epic spanning all time, the rise and fall of the Malacca Empire. Hang Tuah was a major warlord as a Malay warrior who obeys his king, all the more so during the reign of Sultan Mansur Shah of Malacca in the 15th century. This saga is believed to be written around the 1700s (Leiden Manuscript Cod.Or.1762.), But a complete manuscript is dated 1849 AD One excerpt from the manuscript of the Hikayat Hang Tua as follows:
At the time of his youth, Hang Tuah and four of his friends, Hang Jebat, Hang Kasturi, Hang Lekir and Hang Lekiu, kill a bunch of pirates and two others who run amok and create chaos in the village. The Treasurer (together with the Prime Minister in modern terms) Melaka saw their talent and take their duty at the palace. Hang Tuah is enshrined as a hero in the Sejarah Melayu and also narrated in the Hikayat Hang Tuah.

\subsection{Manuscript 'Hikayat Merong Mahawangsa'}

Hikayat Merong Maha Wangsa or history is a saga that tells Kedah traceability Merong Maha Wangsa with the founding of the founding of the state, one of which is located in Malaysia. Although there are some historical facts, this story also contains allegations that impressive. The era covered by this text starting from the opening of the state by Merong Maha Wangsa who claimed to be descendants of Alexander the Great of Macedonia until the arrival of Islam in the 12th century AD Merong Maha Wangsa is Hindu and there are nine other Hindu previous government under his control, which called Phra Ong Maha Wangsa who converted to Islam in 1136 $\mathrm{AD}$ and then took the name as Mudzafar Sultan Shah. In addition, this tale also illustrates the Chola attack on the territory of Kedah. 


\section{Discussion and Suggestion}

Here is some debate as to the findings for further discussions, to serve as input a discussion on Jawi writing applications in various manuscripts in the Malay world, such as the following description:

\subsection{Discussion}

The results of our study as a whole, in this case we can say that the contribution and work of scholars in the form of manuscripts and manuscript turned many into a means of development Jawi writing from time to time by touching everything, especially about the history, language, literature, social, economic, art, culture and so on. In addition, we also found that the most widely used for the works of other manuscripts also based on Jawi writing as promotion of the development of this next as an optional extra in the Jawi script reveals treasures.

Although the Jawi script was influenced by calligraphy that has subtle art of West Africa, in addition to competent bentuknnya, pattern, piled aesthetically attractive features, displaying the beauty of the impressive motif. But the provisions of the Jawi still pose difficulties to the Malays who are not familiar with the intricacies of the text. In order to popularize the use of Jawi writing this, it is not surprising that a lot of players this paper seek ways and methods in order to keep the text as written treasures that remain until anytime. In addition, this paper also expected to be used as a kind of writing that the community in a variety of materials and books, as the frequency of use is said to be of much help to its development. In addition to his writings, also commonly seen Muslim Malaysia in particular and the country in general, to increase the variety of writing that can help the reader to read the works of Jawi through various manuscripts in Malay.

Meanwhile, the existence of Jawi writing which has been intensified by the existence Za'aba and Matlob also began to be associated with Spelling Za'aba (EZ) and the enhanced Spelling (SI) when they were asked to get involved in a committee entrusted with reviewing the Glossary Malay: Rumi -Say-Jawi, first edition, in two volumes, three mold for 2001, 2003 and 2004. Among its members is Tuan Hj. Hamdan Abdul Rahman, Prof. Emeritus Dr. Extremely Mario Moain, Matlob, Prof. Dr. Muhammad Bukhari Lubis, and Ismail Dahaman (former employee DBP). They held a workshop last important on 22-24 March 2002 (Volume I) and 8 to 13 April 2002 (Volume II). Finally came the book Glossary Malay: Rumi-mention-Jawi, the second edition of one volume only, in 2008. All these efforts can produce more perfect method to master Jawi writing up the application are available in a variety of Jawi in Malay manuscripts.

Even their role Matlob Za'aba and they both equally have proved it, they came to highlight their works are impressive, even demanding lovers of Jawi writing since the fifties again, because their works are not solely concerned with writing, but he also developed the science of writing and maintaining quality and quantity. In addition, their publications constantly improved over the years, whether in the form of teaching, for the reading of children, adolescents and adults and so on. Even books and his works remain awake writing accuracy and methods that are structured and accuracy of the method used in it. Perhaps to keep this all, it has resulted in works of their authoritative so widespread in the Malay and even can help the readers and researchers to identify more closely the writings of Jawi are available in various manuscripts in Nusantara guided by the rules of Jawi was founded by two great figures in Jawi.

\subsection{Suggestion}

Here is some debate about the findings of the study should be submitted as a proposal reviewer, to be used as an ingredient in realizing the struggle and Putting the right place Jawi writing methods that have been applied in various manuscripts in Malay so felt almost all over Asia and even the world.

Through this study, it can be stated that almost all states in Peninsular Malaysia including Sabah and Sarawak, according to the luggage museum, institution or library regarding the application of Jawi in various works of the manuscript, it is not impossible to be able to produce generations of leaders and lovers treasure Jawi script for Malays in the Malay world for teaching and learning continues on an ongoing basis. Then applying the method of Jawi in several places throughout the country up to cover all of Southeast Asia, is expected to apply the methods of teaching and learning of Jawi writing correctly and according to the existing rules.

Jawi writing in a variety of applications in the Malay manuscripts can make this paper more precious and valuable to be used as written in various places and fields. And adequate financial assistance shall be extended to further advance the field of Jawi writing of this manuscript, especially in producing new mansukrip required by the Malays. In addition, the Department of Islamic states, is expected to help the development and writing of Jawi writing so it made correctly and interesting, thus giving the impression of external and internal for lovers and researchers. For this, the Islamic Religious Department in the states, or the Writers' Association states, foundations, colleges, institutions, universities and so on are required in order to establish an association or club lovers Jawi, in order to find a talented writer who really can be heir to the greatness of this method ever gemilag in the past.

Also hope the Ministry of Education (MOE), to create a syllabus in secondary schools in teaching writing skills by using the special skills of Jawi writing skills. Then ask also to the lovers and fans of Jawi writing to further enhance the skills to read and write Jawi script and mastery of methods, ranging from the School of Early Childhood (kindergartens and nurseries), Primary School and Sekolah Menengah Kebangsaan (SMK) to the adult stage. In addition, there should be a university or institution which can diversify the program. If the use of Jawi methods necessary to ensure proper use, especially regarding the names, spelling, grammar, uslub and so on. In fact, competition should be held occasionally read Jawi manuscripts all levels in the Malay world to raise the power of the manuscript treasures. 


\section{Conclusion}

In conclusion, should ponder that the application is one of Jawi writing skills in Jawi font with unique diversified in all requirements, in addition to the support from the Arabic, al-Quran and al-Hadith as writing concept sketched. In addition, the use of Jawi writing in various manuscripts in the Malay became one of the fields accounting for the source of Islamic art handicraft as the identity of Malay identity in showing patterns Malay culture in particular and society in general Southeast Asia. It is not independent of meaning, philosophy, shapes, and patterns of work and writing has been described by the authors Jawi cedikiawan ago.

Jawi writing in a variety of applications in the Malay manuscript was complete methods, models, styles and techniques that are useful for Jawi heritage lovers and collectors of old manuscripts in Nusantara. In fact, this makes writing applications in various manuscripts in Malay can make it more valuable and precious to be used as treasures in various places and fields. In addition, the development and activities of the Jawi script should continue to be made with good and interesting, thus giving the impression of external and internal for lovers and researchers in the country. For this, too, must be taken seriously by the Islamic Religious Department in the states, Writers Association states, foundations, colleges, institutions, universities and so on in order to foster the spirit of love for the treasures of the nation in addition to being a remarkable heritage from time to time.

The debate was the focus of discussions among the study is the existence of numerous manuscripts written in Jawi are commonly found in the Malay world with various titles and topics for discussion, such as; Book 'Aqai'id al-Nasafi, Hikayat Raja-Raja Pasai, Manuscript War Batak, Hikayat Amir Hamzah, Hikayat Bayan Budiman, Hikayat Indera Putera, Hikayat Hang Tuah, Hikayat Merong Maha Wangsa, Mass Manuscripts Malay Manuscripts Kitab Tib, Hukum Kanun or law Melaka, Hikayat Abdullah, Manuscript Sulalatul-Salatin, Singapore Burned poetry and so on. Hopefully the exposure of all copies of the manuscript and can provide important information on the heritage of the archipelago to all who need it from time to time.

\section{References}

1. Abdul Razak Ab. Karim, Melestari manuskrip Melayu (Kuala Lumpur: Perpustakaan Negara, 2003)

2. Ahmad Nazuki@ Marzuki Yaakub dan rakanrakan. (2006). Penggunaan kaedah transliterasi dalam buku teks bahasa Arab: Satu kajian kes. Laporan Akhir Penyelidikan. Selangor: Unit Penyelidikan, Pembangunan dan Pengkomersilan Universiti Teknologi Mara.

3. Ahmad Shah Mohd. Noor. (1977). Hikayat raja-raja Pasai. Penyelenggaraan A.H. Hill: Suatu Analisa. T.tp.
4. Ali Hj. Ahmad. Ed, Hikayat Inderaputera (Kuala Lumpur: Dewan Bahasa dan Pustaka, 1979)

5. Alis Murni, Ulasan: Hikayat Inderaputera (Kuala Lumpur: Dewan Bahasa dan Pustaka, 1969)

6. Amat Juhari Moain, Sejarah askara Jawi (Kuala Lumpur: Dewan Bahasa dan Pustaka, 1996)

7. Anas Hj. Ahmad. Sastera Melayu lama dan baru (Selangor: Syarikat Cahaya, 1984)

8. Anas Hashim Musa, Sejarah perkembangan tulisan Jawi (Kuala Lumpur: Dewan Bahasa dan Pustaka, 1999)

9. Arenawati. Perkembangan kesusasteraan Melayu (Kuala Lumpur: Pustaka Antara, 1966)

10. A. Samad Ahmad. Ed, Hikayat Amir Hamzah (Kuala Lumpur: Dewan Bahasa dan Pustaka, 1987)

11. S. B. Baried, Pengantar teori filologi (Yogyakarta: BPPF Seksi Filologi, Fakultas Sastra UGM, 1994)

12. Che Wan Shamsul Bahri bin Che Wan Ahmad, Transliterasi mesin bahasa Melayu: Jawi lamarumi berasaskan petua. Proceeding of the International Conference on Artificial Intelligence in Computer Science and ICT (AICS 2013), 25-26, (2013)

13. Ding Choo Ming, Kajian manuskrip Melayu: Masalah, kritikan dan cadangan (Kuala Lumpur: Utusan Publication and Distributions, 2010)

14. Djamaris, Edward. Hikayat Nabi Mikraj, Hikayat Nur Muhammad dan Hikayat Drama Tasiya (Jakarta: Departemen Pendidikan \& Kebudayaan RI, 1983)

15. Dzulkifli Salleh, Hikayat Merong Mahawangsa sebagai sumber sejarah (Kuala Lumpur: Dewan Bahasa dan Pustaka, 1965)

16. E. S. kadjati, Katalog induk naskah-naskah Nusantara jilid 5A: Jawa Barat koleksi lima lembaga (Jakarta: Yayasan Obor Indonesia, 1999)

17. A. T. Gallop, The British library journal 17 (2), (1991)

18. A. T. Gallop, Warisan warkah Melayu (London: The British Library, 1991)

19. Harun Mat Piah, Kesusasteraan Melayu tradisional (Kuala Lumpur: Dewan Bahasa dan Pustaka, 1993)

20. Harun Mat Piah, Cerita-cerita panji Melayu (Kuala Lumpur: Dewan Bahasa dan Pustaka, 1977)

21. Hashim Abd Hamid (2004) Doksologi dalam Manuskrip. Kertas Kerja dalam Seminar Manuskrip Islam pada 1-2 Mac 2004, Anjuran Jabatan Perdana Menteri Negara Brunei Darussalam.

22. Ibrahim Saad, Kesusateraan Melayu: Satu pengenalan (Kuala Lumpur: Utusan Melayu, 1974) 
23. Ismail Hussien, Sejarah pertumbuhan bahasa kebangsaan kita (Kuala Lumpur: Dewan Bahasa dan Pustaka, 1984)

24. Jones, Rusell, Hikayat raja Pasai (Petaling Jaya: Penerbit Fajar Bakti, 1987)

25. Kamus Padat Bahasa Malaysia-Inggeris (Sri Serdang: Penerbit Minda Sdn. Bhd., 2008)

26. Kamus Dewan edisi keempat, (Kuala Lumpur: Dewan Bahasa dan Pustaka, 2010)

27. Kassim Ahmad, Hikayat Hang Tuah (Menurut naskhah Dewan Bahasa dan Pustaka) (Kuala Lumpur: Dewan Bahasa dan Pustaka, 1964)

28. Khalid Hussein, Taj us-Slatin (Kuala Lumpur: Dewan Bahasa dan Pustaka, 1966)

29. Muhammad Bukhari Lubis, Ali Haji Ahmad, Transliterasi kata Arab-Parsi-Turki (Kuala Lumpur: Utusan Publication \& Distributors Sdn. Bhd., 2006)

30. Muhammad Bukhari Lubis, Makmur Haji Harun dan Alizah binti Lamri, Jawi: Warisan warga Alam Melayu (Tanjong Malim: Penerbit Mentari, 2013)

31. H. Muhammad Yusuf, Persejarahan Melayu Nusantara (Kuala Lumpur: Teks Publishing Sdn. Bhd., 1988)

32. Raja Ali Haji Raja Haji Ahmad. (1892). Bustan al-Katibin. T.tp.

33. S. Siti Hawa, Hikayat Merong Mahawangsa (Kuala Lumpur, University of Malaya Press, 1970)

34. Siti Hawa Salleh, Masalah pengeditan manuskrip Melayu. (Kuala Lumpur, University of Malaya Press, 1978)

35. H. Soebadio, Penelitian naskhah lama Indonesia (Buletin Yaperna, 2010)

36. N. S. Suryani, Teori filologi. (Bandung, Fakulti Sastera Unpad, 2006)

37. N. S. Suryani, Filologi (Bogor, Ghalia Indonesia, 2012)

38. Sutrisno, Sulastin, Hikayat Hang Tuah: Kajian struktur dan fungsi (Yogyakarta, Gajah Mada University Press, 1983)

39. Syed Muhammad Naguib Al-Attas, Islam dalam sejarah dan kebudayaan Melayu (Bangi, Universiti Kebangsaan Malaysia, 1972)

40. Wan Ali Wan Mamat, Pemuliharaan buku dan manuskrip. (Kuala Lumpur, Dewan Bahasa dan Pustaka, 1988)

41. R. O. Winstedt, A History of classical Malay literature (Kuala Lumpur: Oxford University Press, 1977)

42. R.O. Wolters, History, culture and religion in Southeas Asian perspectives (Singapura: Institute of Southeas Asian Studies, 1882)

43. Website

http://ms.wikipedia.ogr/filologi asia, india, nusantara dan moden http://www.naskah-naskahlama.blogspot.com/naskahaceh.blogspot.com/ http://www.manuskriplama.blogspot.com. http://www.utusan.com.my/utusan/Bicara_Aga $\underline{\mathrm{ma} / 20130118 / \mathrm{ba} \text { 06/Kerja-penulisan }}$
manuskrip-Melayu\#ixzz21LMU6ckk (CUtusan Melayu (M) Bhd. 